\title{
ICOM \\ Wildlife comics, or the making of young naturalists in late Franco's Spain (1969-1970)
}

\section{Carlos Tabernero}

Abstract

Keywords

DOI

Introduction
This essay examines a highly popular comic series published in Spain between 1969 and 1970 which focused on Felix Rodríguez de la Fuente (1928-1980), a prominent and influential naturalist and media icon, as main character. These comics constitute a remarkably illustrative example of the use of popular media in processes of construction of natural history knowledge. Situated in the complex final years of Franco's regime, they allow us to probe the combined role of science, media, and celebrity in the construction of a visual environmental culture through storytelling strategies designed to engage young audiences in naturalist-like practices.

Environmental communication; Public engagement with science and technology; Visual communication

https://doi.org/10.22323/2.21010205

Submitted: 31st October 2021

Accepted: 23rd December 2021

Published: 21st February 2022

This essay analyses a group of comic series about nature published in two widely popular Spanish magazines between 1969 and 1970. These comics featured Félix Rodríguez de la Fuente (1928-1980; FRF hereafter), at the time already a well-known naturalist, activist, natural history author and rising television star [Tabernero, 2016], as the source of their motivation, implicit technical and plot supervisor, and main character. Created by prominent Spanish cartoonists, these drawn narratives were mainly of two kinds: fiction stories where FRF played a central role owing to his position as a naturalist and broadcaster; and educational pieces that echoed his publishing and TV documentary productions. In addition, they were eventually coupled with a Q\&A section fundamentally addressed, like the whole endeavour, to young readers, to foster their environmental awareness and, consequently, engage them in natural history and practices.

The aim here is to contribute to the understanding of the cross-platform storytelling strategy concerning natural history knowledge produced by FRF in the final years of Franco's dictatorship. Developed in a highly intricate context as regards politics, science, and media, FRF's comics constitute an illustrative example 
of a science popularization approach produced specifically to engage young audiences in processes of construction and application of scientific knowledge. This was particularly remarkable given that the dictatorship persistently used all available media to indoctrinate and discipline the population, and to shape representations of the regime that were largely reliant on generating positive attitudes of adherence to the rulers through people's submission and obedience to experts. Consequently, we will probe these comics' necessary compliance with the regime's media communication standards and restrictions. In this sense, it is worth noting that FRF established himself as a celebrity natural history populariser in the 1960s through the skilful navigation of the regime's administrative, academic and media procedures through the establishing and calling on political and academic connections. He thus erected an increasingly interlocking multi-platform media structure that incorporated research, education, activism, and entertainment means and purposes, and with which he managed to attract considerable public attention to his nature conservation messages [Tabernero, 2018]. The comics we analyse here responded to, and further amplified this ambitious endeavour.

FRF's openly declared mission was to change Spaniards' perception of their relationship with the environment within a context of increasing urban and industrial development. Franco's regime considered every corner of Spanish territory as a pool of resources ripe and available for exploitation, and every unproductive or uncooperative element, such as wildlife at large, was expendable. But FRF, perceptively, took careful note of the sweeping changes in the socio-cultural and media landscapes that were taking place in Spain at the time, which contributed to his resolve to publicise his activities as falconer, naturalist, and activist. In the context of people's increasing mobility and the wider circulation of information, owing to more frequent and wider migration flows and the expansion of tourism, where television was turning into the main vehicle for personalised content consumption, and with the natural sciences growing as a significant field of social, political, and cultural negotiation, he sought exposure for a wide range of audiences. In this sense, he realised from the beginning that it was essential to reach households at a time when access to education and information was not necessarily a given. And popular media were key elements to his achievement of these goals.

In terms of popular media, comics have been largely overlooked as sources of information for historical and socio-cultural scrutiny. The consideration of this medium from its beginnings as a low-quality, suspicious and unorthodox cultural derivative, along with its characteristic affiliation with epistemologically undervalued youngsters and children, have contributed to its continuing and widespread belittlement [Goulart, 2000; Hajdu, 2008; Jones, 2011]. Still, as happens with other mass media, comics are rich in conceptualizations of nature, natural heritage and the environment, and thus deserve, particularly considering their traditionally immense audiences, to be taken into account to understand contemporary processes of construction and validation of natural history knowledge.

To further our analysis, we will contextualise FRF's comics within the history of the medium in Franco's Spain [Moix, 2007; García, 2010; Altarriba, 2011], ${ }^{1}$ as well as

\footnotetext{
${ }^{1}$ Concerning the disregard of popular culture as epistemologically significant, also regarding Franco's dictatorship, see Labanyi [2002].
} 
within a larger framework of science popularization [Hilgartner, 1990; Daum, 2009], paying specific attention to the production of science comics [Farinella, 2018]. We will examine the extent to which they mirrored, and simultaneously contributed to, the development of an extremely successful early transmedia effort for the circulation of natural history knowledge [Jenkins, 2010; Tabernero, 2018]. We will then focus on how FRF blended narrative tropes related to notions of wilderness as a societal building device to convey, by himself becoming a character in fiction stories, a clear-cut, patriotic male everyday-worker scientific ethics concerning attitudes towards nature and the environment [Daum, 2004; Augustine, 2007; Andrews, 2013; Somsen, 2017]. In this sense, we will also examine how FRF's celebrity status played a crucial role in the description and establishment of epistemological ranks dealing with natural history practices and the production of narratives about nature [Turner, 2004; Bell and Gray, 2007; Brockington, 2008; Kirby, 2008; Gouyon, 2011]. ${ }^{2}$ And finally, we will analyse how, through various means, he merged all these elements in a very successful feedback loop that included fostering his audiences' direct correspondence with him, thus developing an additional communication activity to enthusiastically engage children and youngsters in naturalist-linked practices in their everyday-life. As a result, the comics we analyse here further contribute to the historical understanding of the intricate relationship between communication practices, popular media, and the processes of production, circulation, and management of scientific knowledge, particularly with respect to the development of contemporary environmental thought.

An inviting depiction of natural history and broadcasting practices
On 16 October 1969, the youth magazine Gaceta Junior featured the announcement of the 'sensational signing' of 'Felix, the friend of animals' on the cover of issue $53 .{ }^{3}$ It was accompanied by a full-page colour drawing of the featured guest, well-known naturalist and then rising television star FRF, who was portrayed, in a sort of content and knowing attitude, holding a falcon and surrounded by two wolves, a tiger and a lion (see Figure 1).

Inside, page 9 was devoted to explaining the ad, and featured a black and white limited preview of a series titled "Fauna': the adventures of Félix', a photograph of

\footnotetext{
${ }^{2}$ In late Franco's Spain, education was central, always linked to propaganda and indoctrination aims and needs, and constructed upon an unambiguous hierarchy of providers and receivers of meaning, knowledge, and its application. The state-controlled television (Televisión Española) was pivotal in relation to the development of media science content at a time when natural history was becoming, internationally, a significant field and experimental arena for the design of education strategies through media. FRF's entrance in the medium in the 1960s brought natural history clearly to the forefront, very much like David Attenborough or Jacques Cousteau in their respective contexts [Scott, 2003; Olmstead, 2008; Salcedo, 2008; Louson, 2018; Gouyon, 2019]. Typically, wilderness was represented as a highly alluring trope for a techno-scientifically informed stewardship of resources, associated to identity-driven and hierarchically-built means and modes of social organization, a compelling political tool, useful for propaganda and policy strategies when applicable to the rhetoric about the improvement of collective welfare conditions [Cronon, 1996; Bocking, 2004; Nelson and Callicott, 2008; Agar and Ward, 2018]. Thus, media outputs effectively account for the development and interaction of subjectivities and experiences about nature, and the eventual creation of power relations, of agent and non-agent subjects [Irwin and Wynne, 1996; Callon, 1999; Hilgartner, 2000; Neumann, 2002; Jasanoff, 2004; Armiero, 2008; Wakild, 2011; Tabernero, 2022].

${ }^{3}$ Gaceta Junior was a weekly published through Editorial Universo Infantil, S.A. (1968-1971) by the powerful media conglomerate Godó Publishing [Cuadrado, 2000].
} 


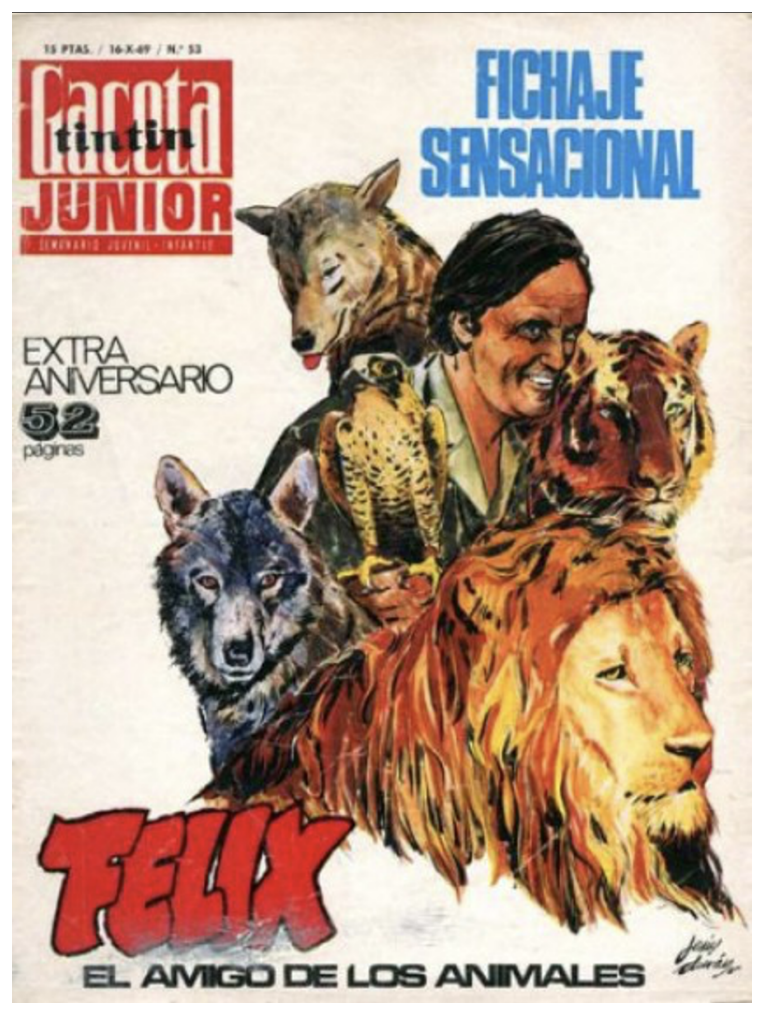

Figure 1. Gaceta Junior 53 [1969], cover.

Jesús Durán and Enrique Sánchez Pascual, ${ }^{4}$ cartoonist and scriptwriter of the series, seemingly at work, and a letter to readers penned by FRF himself. Under the heading "Félix" writes: this is how my section will be', FRF called the initiative, for which he credited Durán, a 'page dedicated to the study of animals', and went on briefly describing many of the animals that were to be featured in the series. Then, he added:

\begin{abstract}
Soon, I'm sure, you'll be incredible specialists and talk about all the animals in the world. But you already know that I am working on another idea... and very soon I'll give you a big surprise; but, for the moment, I'm here, in GACETA JUNIOR, waiting for your letters.

[Gaceta Junior 53, 16 October 1969, p. 9]
\end{abstract}

The tone of the announcement shows that FRF was already well known to the readers. The use of just his first name, the corresponding informal language of the letter, and his certainty about the readers' anticipation of his next venture, denote a close relationship with audiences that were already familiar with his many media outputs. ${ }^{5}$ In fact, his status as a rising television star had just been cemented by his first program as director and host, Fauna (1968-1970), which was broadcasted for

\footnotetext{
4Jesús Durán Castillo (1938, cartoonist) and Enrique Sánchez Pascual (1918-1996, scriptwriter) were highly respected in the Spanish and international comics field from the 1950s through the 1980s [Altarriba, 2011].

${ }^{5} \mathrm{By}$ that time, he had already contributed luxurious wildlife features in the widely distributed magazines Blanco y Negro (1966-1968) and La Actualidad Española (1968-1970) and contributed to four shows on Spanish Public Television (Televisión Española): Fin de semana (1964), Televisión Escolar (1966), Imágenes para el saber (1967), and A toda plana (1967) [Salcedo, 2008; Tabernero, 2016].
} 
the first time on 20 October 1968. And by the time issue 53 of Gaceta Junior was distributed, he had already received hundreds of letters, many of them from children and young people, congratulating and thanking him for his media outputs, but also asking him questions about not only wildlife but also, significantly, details of his work as a naturalist and media professional [Tabernero, 2016; Tabernero, 2018].

The design of the cover and the, at the time, purported title of the series, 'Fauna', reveal an unambiguous will to strengthen the cross-platform approach FRF had set in motion to expand his audience reach and bolster his nature conservation messages. The animals that surrounded FRF in the cover image not only denoted the promise of adventures, but also unequivocally alluded to the varied endeavours that had made him a widely known popular figure: falconry, his struggle for the protection of wolves, and his African photographic safaris. ${ }^{6}$ In addition, his nickname, 'the friend of animals', was the brand alias he had used for the first time in his appearances on Television Escolar (1966), and which he continued to persistently use in all his subsequent media outputs. And the title 'Fauna' was a two-way opportune advertisement for both the comic series and the TV show of the same name that had been being broadcast for a year at that point, although this proved to be an ephemeral promotional device: the comic series was finally published under the heading 'Félix presenta: Mundo Animal' ('Félix presents: Animal World').

This series consisted of nine instalments, which were to be unevenly featured from the following issue, on 23 October 1969, to the New Year special issue on 31 December 1969. ${ }^{7}$ Each instalment was a double page spread that focused on one animal, details of whose habitat, behaviour and life cycle were narratively described. The series would later continue in another magazine with a much greater print run and impact, Gran Pulgarcito, as 'Gran Fauna' ('Big Fauna') (see Figure 2). In this case, there were thirteen consecutive instalments in issues 72 to 84 , published over the summer of 1970 , from 8 June to 31 August. ${ }^{8}$ While maintaining the same concept, their length was, however, doubled to four pages, and new illustrators also contributed to the series. ${ }^{9}$

Jesús Durán, creator of the comic series discussed in this paper, produced them in a naturalistic style. This was the same creative tradition all the contributors had built their reputations upon since the 1950s, while drawing male heroes in war, cowboy,

\footnotetext{
${ }^{6}$ These activities had been featured in the official newsreel NO-DO $(1956,1957,1964)$; in the powerful Spanish newspaper $A B C(1960,1962,1964)$; in his appearances on TV since 1964, including his first solo show Fauna (1968-1970); in his book El arte de la cetrería (1965); in his first documentary film, Alas y Garras (1967); and in the magazines Blanco y Negro (1966-1968) and La Actualidad Española (1968-1970). [Tabernero, 2016; Tabernero, 2022].

${ }^{7}$ Gaceta Junior 54-59, 62-63, and the New Year special issue [1969].

${ }^{8}$ Gran Pulgarcito 72-84 [1970]. Gran Pulgarcito was the last version, at the time, of the renowned title Pulgarcito, which the influential Bruguera Publishing Company had started back in 1921, when the firm was called El Gato Negro. Bruguera was the most important publishing group in Spain specializing in publications for young readers. While the print run of Gaceta Junior consisted of a modest, albeit significant 70,000 copies by 1970, Gran Pulgarcito's run consisted of around 600,000 copies, therefore being one of the three main weekly comic magazines at the time, all of them published by Bruguera [Vázquez, 1973; Cuadrado, 2000; Guiral, 2010].

${ }^{9}$ Adolfo Usero Abellán (1941), Leandro Blasco Ballestar (1936-2000) and Andrés Balcells Velayos were very respected cartoonists within the Spanish comics publishing panorama from the 1960s through to the 1990s [Altarriba, 2011].
} 


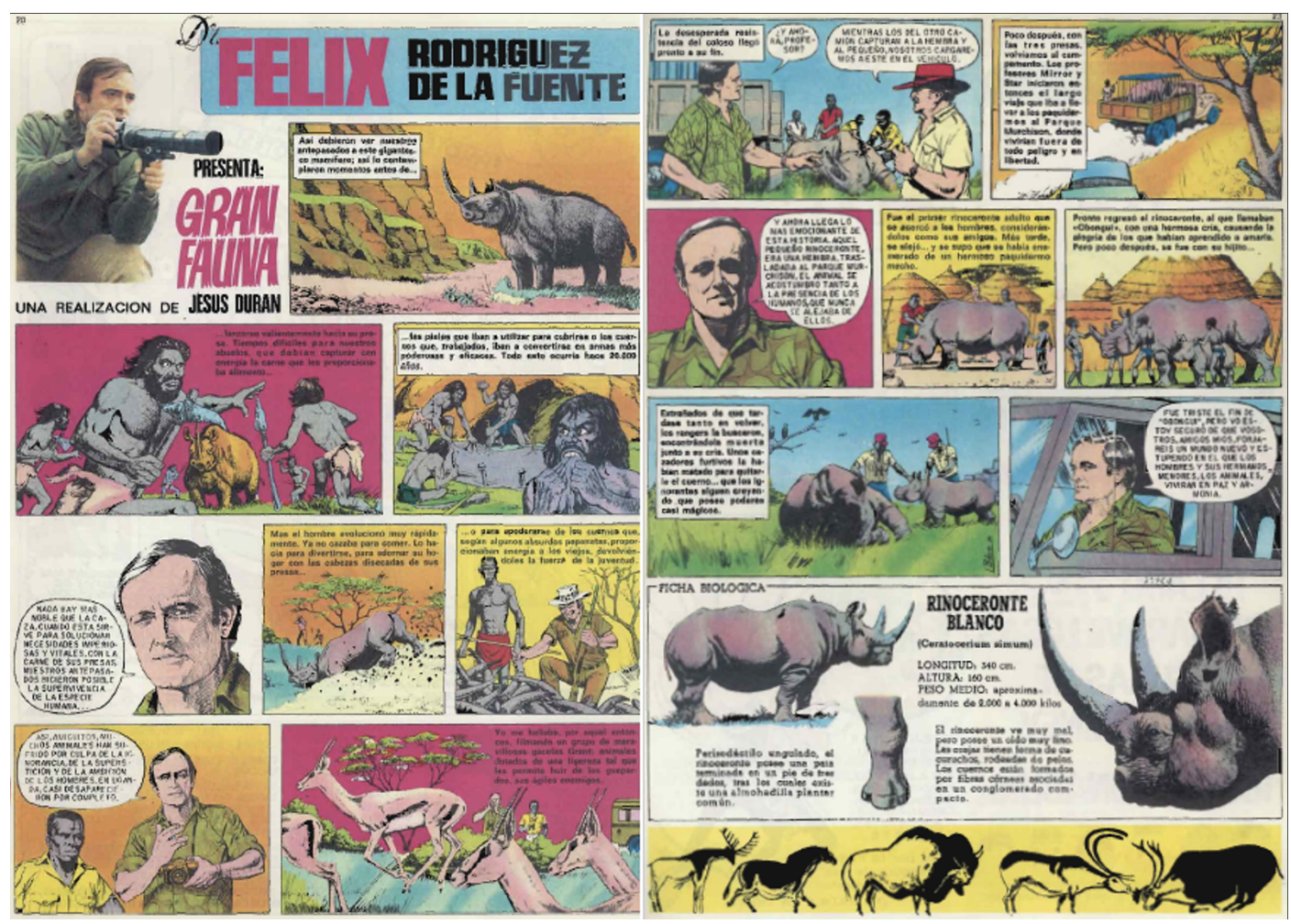

Figure 2. Gran Pulgarcito 72 [1970], pp. 20 and 23.

medieval or noir adventures, or romantic tales targeted specifically at girls, and in highly popular graphic novels, all of which sold well on the newsstands [Jiménez Varea, 2011; Altarriba, 2011; Pintor Iranzo, 2017]. This naturalistic take operated at two levels, at least: to start with, it imbued the narratives with a deliberate touch of authenticity, thus directly appealing to the readers' belief in the credibility of the stories [Goulart, 2004]. Such approach aimed at bringing plots and their socio-cultural implications closer to the everyday lives of readers, and consequently became a major issue in the long and dramatic socio-political contention about the alleged pernicious effects of comics on children and young people [Hajdu, 2008; Fernández Sarasola, 2019]. ${ }^{10}$ As a result, some publishers tried to distance their productions from those in the eye of that storm by producing 'good comics', particularly educational, which focused, among others, on science topics, and followed a naturalistic documentary style to conform to a socio-politically sanitised impression of authenticity and credibility. ${ }^{11}$

The 'good comics' approach was the main standpoint of the Spanish production following the Civil War. While having to reinvent itself in a context of rigidly

\footnotetext{
${ }^{10}$ Comics were blamed for what was perceived as an increasing problem of juvenile delinquency, linked to a clear distinction between popular and high culture and their respective targeted audiences. The process reached its peak when psychiatrist Fredric Wertham famously argued against comics from a medical perspective in his influential Seduction of the Innocent [1954].

${ }^{11}$ In the U.S., the EC comics series Picture Stories from the Bible (1944-1946) was praised in Catholic circles that, at the same time, where actively campaigning against comics. In the same spirit, Picture Stories from American History (1945-1947) and Picture Stories from Science (1947) consisted mainly of biopics. Other science-related comics which also exploited patriotic topics were: True Comics (1941-1950), DC's Real Fact Comics (1946-1949), Frontiers of Science (1961-1979) or publicity-related mashups, such as Radio Shack Comic Books (1972-1991) [Goulart, 2004; Burns and Leach, 2011; Leach, 2015].
} 
imposed censorial control, highly restrictive publication regulations, and unfavourable financial conditions, the medium embraced the naturalistic, educational approach to convey the socio-cultural ethics imposed by the regime's national-Catholic order. ${ }^{12}$ The main narrative tropes employed attempted to transmit the regime's deliberate historical rupture with the recent Republican past and reinforce the new socio-political order through medieval-crusade and idealised urban tales, all of which tended to mould the regime's versions of superheroes that positioned Spain as a bastion for western, male Catholic values. ${ }^{13}$ Among them, there were a few productions, albeit rather ephemeral, that used science either as their main focus or as an essential backdrop for plot development. ${ }^{14}$

Besides the conscious distancing from potentially harmful caricature-like styles that were commonly used in newspaper comic strips and satirical or teenager publications, the naturalistic approach also incorporated a sense of seriousness and rigor in contrast to the theoretically more ingenuous and puerile approaches designed 'just' for fun. In Gran Pulgarcito, FRF's comics were being published alongside some of the most critically acclaimed Spanish and European comic series in history, such as Jean Giraud's stylistically realistic cowboy series Blueberry (b. 1963), Francisco Ibáñez's Mortadelo y Filemón (Mort and Phil, b. 1958), and René Goscinny and Albert Uderzo's Asterix (b. 1959) (see Figure 3), all of them mainly targeting children and teenagers. Mortadelo and Asterix appealed to a wider range of ages, managing to introduce mature socio-cultural critique within children's parodic slapstick, while Blueberry offered the realistic counterpoint, equally charged, but reminiscent of film adventures (westerns) for teenagers and adults. FRF's Mundo Animal and Gran Fauna then operated like a bridge: stylistically, they were closer to Blueberry as well as to other nature-situated, exotic-colonial stories, such as Tunga, la tribu de los cazadores (Gaceta Junior, 1968-1969; Spanish version of the French comic Tounga: La Horde Maudite, 1964) and Sambhur (Gaceta Junior, 1969; 1971); but they also appealed to audiences that were keen on stories such as Safarino (Gaceta Junior, 1969), which exploited a caricature-like, anthropomorphic take on wildlife. ${ }^{15}$

In this context, 'Mundo Animal' and 'Gran Fauna' introduced two ground-breaking elements: first, the presence of FRF himself as a knowledgeable host. With the undeniable demeanour of a media professional, often depicted camera in hand, he presented what looked like the result of either his own research

\footnotetext{
${ }^{12}$ The 1938 Spanish Press Act subjected comics to the same censorship regulations as the press. An additional problem in the 1940s and 1950s was the scarcity of paper. Given the restrictions they encountered in maintaining weekly or even monthly publications, publishers constantly experimented with creative formulas to expand their business and reach through both content and form [Fernández Sarasola, 2017].

${ }^{13}$ Some well-known examples are Roberto Alcázar, el intrépido aventurero español/Roberto Alcázar y Pedrín (1941-1976), El guerrero del antifaz (1944-1966; 1972-1980) and El capitán Trueno (1956-1968; 1968-2017) [Altarriba, 2011].

14Such as: Red Dixon (1954-1957), Diego Valor (1954), Kit boy (1956), Platillos volantes (1956), Mundo futuro (1956-1957), Hazañas de la juventud audaz (1960), Kosman (1960), and Rock Vanguard (1961) [Altarriba, 2011].

${ }^{15}$ It is also of interest that the naturalistic take of FRF's comics was closer to the educational approaches of western democracies than those of, for instance, eastern European communist regimes, such as Mosaik and Wattfraß, in East Germany, or Tekhnika Molodezhi in the Soviet Union, which focused on more caricature-like promotion against the western evil view of scientific development and its applications [Augustine, 2007; Andrews, 2013].
} 
or his study of the natural sciences. ${ }^{16}$ While appealing directly to the aesthetics of documentary films, his presence as a character would serve to change the public's view of nature as a distant, mysterious though fascinating wilderness, and characterise it as a space in need of care and study from the urban, academic, and, as depicted in the comics, overtly colonial quarters where scientific knowledge was produced [Cronon, 1996; Nelson and Callicott, 2008].

The second innovative element, which effectively stressed the educational character of these comics, was the introduction of the scientific names of the animals introduced in each instalment and, as an integral part of the narrative, of collectable cards with scientific data about them (see Figure 2). This pointed to the need to acquire a rigorous methodology to reach FRF's level of achievement, while enhanced the sense of authenticity, trust, and credibility. This approach of providing the public with straightforward and understandable scientific data became a staple of FRF's work: from the graphics he used in his early classroom-like TV sets, and in his magazine pieces and encyclopaedias, to him later showing his own field notebooks in his principal TV series, Man and the Earth (1974-1981), and which would be published as a collection in 1978, thus ultimately closing the loop with his scientific research becoming directly available in the everyday lives of his audience. As such, 'Mundo Animal', 'Gran Fauna' and all these media outputs were as much about wildlife as about the natural sciences and journalism as professional careers. These comics were unambiguously promoting the natural sciences as a field of interest, a way of living, and a world of possibilities as regards a life of adventure, knowledge and even celebrity, such as FRF's. Moreover, they were an implicit invitation, through FRF's personal example, to join a life devoted to the natural sciences as the way to get out of the backwardness that had long been socio-culturally (self)-perceived as an identity trait of the Spanish population [Tabernero, 2018; Tabernero, 2022].

The biopic of the righteous white male hero
'Mundo Animal' and 'Gran Fauna' were devised as one more window to FRF's hands-on venture in the pursuit of natural history knowledge. The aim, as with all his media endeavours, was to create or raise audience awareness of the environment, together with the promotion of the natural sciences, in first place, and natural history journalism, as feasible career prospects. As he depicted it, the job was to study and understand nature so that it could be properly managed, protected and told, and such work offered opportunities to travel far and wide, and to live adventures in close contact with the remote wilderness. This was particularly enticing in a context where travel, domestic or abroad, other than forced economic or political migrations, was just starting to be explored by some Spanish people. Tourism was a fledgling industry, which targeted a growing middle, urban and consumer class. Urban Spaniards were encouraged to colonise, alongside European tourists, the wild seashores and mountains of the Iberian Peninsula [Sánchez Sánchez, 2001; Breiby, 2014]. FRF himself had been involved in the promotion of nature-oriented tourism, with a touch of regime-sanctioned medieval history, through his falconry-based project El castillo de los halcones (The castle of falcons, 1964), which was never carried out, but nevertheless contributed to the foundation of the luxurious network of Spanish Paradors [Tabernero, 2016].

\footnotetext{
${ }^{16}$ His character in these comics was reminiscent of what had been previously seen on TV and film works by David Attenborough and Jacques Cousteau [Chris, 2006; Olmstead, 2008; Gouyon, 2019].
} 


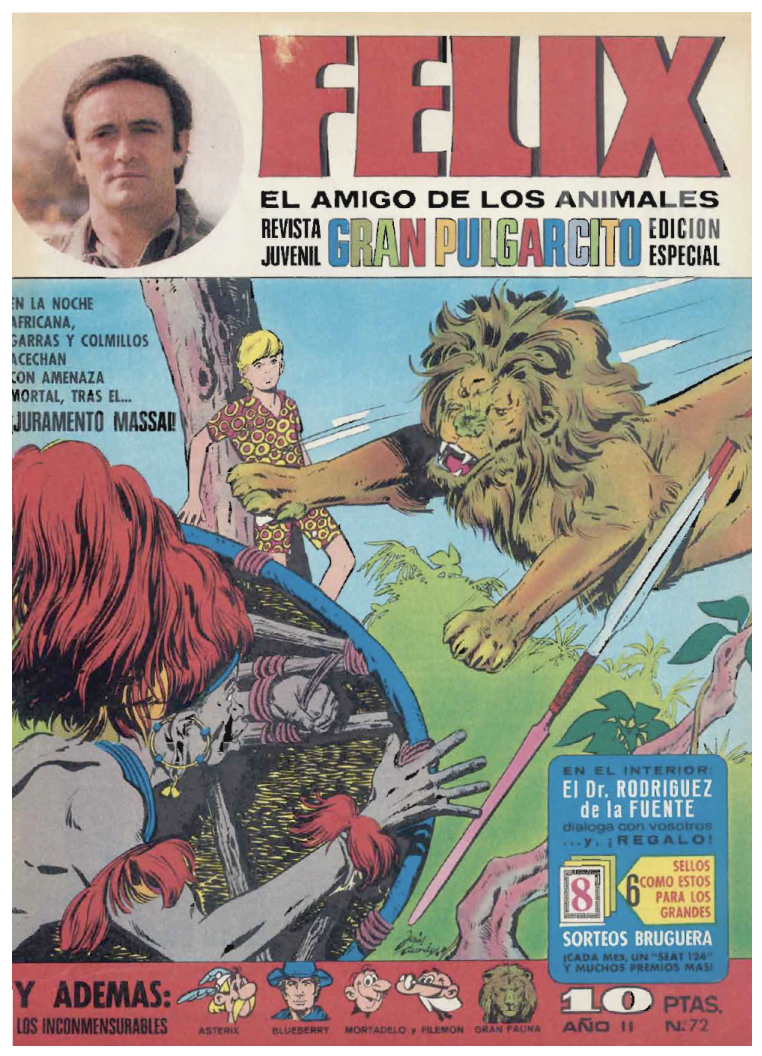

Figure 3. Gran Pulgarcito 72 [1970], cover.

Likewise, from his initial endeavours as a falconer, he included Iberian wildlife in his natural history media production to acquaint Spanish urbanites with their neighbouring nature, the wonders of which he often portrayed alongside the customary footage of African fauna. This was one of FRF's main contributions to natural history broadcasting in Spain. Four of the nine instalments of 'Mundo Animal' were devoted to autochthonous species. But this strategy soon changed when the comics moved to Gran Pulgarcito. Jesús Durán, FRF, and the publishers had to be certain of the success of the venture, as this was a much more ambitious project. First, the publishers turned the magazine's long-standing and easily recognizable title Gran Pulgarcito into a subtitle, retitling the publication as Félix, el amigo de los animales (Félix, the friend of animals). Then, in addition to 'Gran Fauna', a new, parallel series was introduced, 'Safari en África' ('Safari in Africa'). ${ }^{17}$ The primacy of this new series was further enhanced by its presence, through its entire run, on the cover, which always featured a picture of FRF as well (see Figure 3).

'Safari en África' dramatically expanded the attributes of 'Mundo Animal' and 'Gran Fauna' into the world of fiction. It followed the 'good comics' approach to the letter: in the context of Franco's regime and its tight control of media production, these comics adhered to the narrative conventions of adventurous biopics, which were very much to the regime's liking, to put across scientific

\footnotetext{
${ }^{17}$ Gran Pulgarcito 72-84 [1970]. This series soon moved to another weekly, Bruguera's continuation and equally popular heading, Super Pulgarcito [Guiral, 2010], under the title 'Una aventura con Félix, el amigo de los animales' ('An adventure with Félix, the friend of animals'), keeping the same spirit even though new staff cartoonists were recruited to contribute and printed in monochromatic sepia as opposed to fully colored [Super Pulgarcito 1-8, December 1970-February 1971].
} 
content. These narratives provided the possibility to exploit ideological and nationalist perspectives to articulate propaganda goals concerning the need to depict and establish excellence in the pursuit of socio-economic relevance. In addition, they straightforwardly followed the socio-politically favoured schema of the male righteous battle against evil. Thus, the casting of FRF as the main character effectively made him a living hero whose life and works were as much worth depicting and consuming as those of the fictional heroes that had filled the pages of previous publications through decades.

This step showed the enormous possibilities of FRF's transmedia approach through which to bring scientific knowledge of wildlife and the environment into Spanish households [Tabernero, 2018]. He was already using epic narratives in his photographic reports and his TV programs, and his resorting to emotionally charged, dramatic narrations would only keep increasing across his media outputs. Here, just like the famous scientists and explorers of biomedical and techno-scientific biopics, ${ }^{18}$ FRF was a hero in the stories because of his line of work. His adventures were an epically embodied depiction of the everyday life of a hardworking scientist who was, at the same time, a self-made worker and champion of the regime. Accordingly, as 'the Spanish naturalist', he personified the values of rigorous study, self-sacrifice, and co-operative work, all wrapped in the adventurous envelope of bravery and creativity necessary to help solve conflicts. In the convoluted plots of 'Safari en África', the naturalistically rendered African savannah was the backdrop and motivational epitome of that sublime and dangerous wilderness where the civilised man had to face the contradictions of his urban-industrial condition through his duty to investigate, understand, control, and thus protect it. For better or worse, wilderness was at the mercy of the men of the powerful techno-scientific, developed world, the 'Masters of Nature' [Plumwood, 1993].

FRF's work as a naturalist and wildlife filmmaker allowed him to be at the eye of the storm, in an exotic, adventurous, international and overtly colonial space where struggles concerning the environment constantly emerged and required intervention: the selfish, thoughtless and ruthlessly exploitative consideration of the colonial wilderness, personified, in particular, by western poachers, was consistently opposed to the, also western, behavioural and management ethos based upon scientific knowledge and professional proficiency, that was embodied by naturalists and governmental managers. Therefore the 'bad guys' were mainly white males, so self-absorbed by their combined urban-industrial, colonial and consumer condition, that they could not care less about nature and its rightful non-human dwellers, which they would destroy on behalf of greed and arrogance. FRF antagonised them with the aid of the authorised professionals of the developed world who oversaw the scientifically informed management of landscape, research, or trade tasks, mainly involving the care of wildlife, and with whom he was already acquainted.

The coloniality of these contexts was justified on behalf of the scientifically informed environmental protection: indigenous peoples and women conformed a subaltern class of necessary contributors to the legitimate activities of the

\footnotetext{
${ }^{18}$ Examples in Franco's Spain were featured in the popular collection Vidas Ilustres (Ediciones Recreativas S.A., 1956-1974, originally published by Editorial Novaro in Mexico) [García, 2010; Altarriba, 2011].
} 
self-sacrificing and knowledgeable white male technocrat administrators. Women were simply in charge of household duties as mere companions and aides to male righteous characters. And the black male locals were either at the service of the white managers, and thus dressed as westerners, or were living in their tribes with their 'exotic' clothes and gear, that is, as part of that wilderness which was to be managed and studied according to western scientific standards. They were also often involved in the conflicts, mainly because of a combination of ignorant selfish pursuits and their cultural superstitions, which were efficiently counteracted by scientific righteousness. In the end, indigenous peoples and women would eventually participate in the resolution of conflicts, but as secondary social actors owing to their gender, race and/or class, often becoming the grateful and lucky receivers of the application of the overtly green colonialist knowledge displayed [Camprubí, 2020; Armiero and Graf von Hardenberg, 2013]. ${ }^{19}$

Children and teenagers, on the other hand, were configured as a special case of subaltern character. As the main target audience, they were sometimes cast as protagonists because of their emotional attachment to animals. In such cases, conflicts were developed to show the need to think carefully and apply the results of the rigorous study of the natural sciences to fulfil that emotional attachment in the best interest of both humans and non-humans alike in the all-enveloping and unforgiving wilderness (see Figure 4). Youngsters, then, became the projection into the future of all these actions, the building blocks of a future, perfectly advanced, and morally correct techno-scientific society, able to appreciate the environment as an extremely valuable asset. Significantly, the gender stereotype depiction was broken, just once, simply because the female condition of the character in question was outdone by her condition as a teenager. ${ }^{20}$

In all, the promotion of the naturalist and broadcaster careers, together with the nature conservation messages, operated in these stories far beyond the usual willing suspension of disbelief associated with the consumption of fiction. 'Gran Fauna' provided a documentary-like sense of rigor, authority, and trustworthiness; 'Safari en África' appealed, through fiction, to people's preferred everyday media consumption practices; and both series explicitly established links with FRF's well-known activities as naturalist and broadcaster (see, for instance, the ending in Figure 4), strengthening the narrative identification with the professional and ethical example of a hero who was, implicitly, a product of the regime.

The transmedia approach thus greatly contributed to fashioning the Spanish celebrity naturalist: in these comics, he epitomised the successful and outstanding scientist and broadcaster, able, due to his job, rigor, and tenacity, as well as his adventurous spirit, to mingle, as a person of parallel status, with powerful members of the hegemonic powers of the western block. This therefore constituted a projection of how Franco's Spain was becoming modernised at a fast enough rate to take its rightful place in the international arena. Moreover, FRF, as a modern-day paladin of environmental conservation, exemplified a scientist whose Wissenschaft

\footnotetext{
${ }^{19}$ Concerning the nuances of the international and colonial discourses featured in these comics, particularly in relation with knowledge management processes, see also: Kusiak [2010], Gissibl, Höhler and Kupper [2012] and Wheatley [2013]; and specifically in relation with Franco's regime legitimation goals at home and abroad, see: Medina-Doménech [2009], Tabernero, Jiménez-Lucena and Molero-Mesa [2017] and Camprubí [2020].

${ }^{20}$ 'La noche de los licaones' ('The night of the African wild dogs'), Gran Pulgarcito 74 [1970], pp. 8-15.
} 


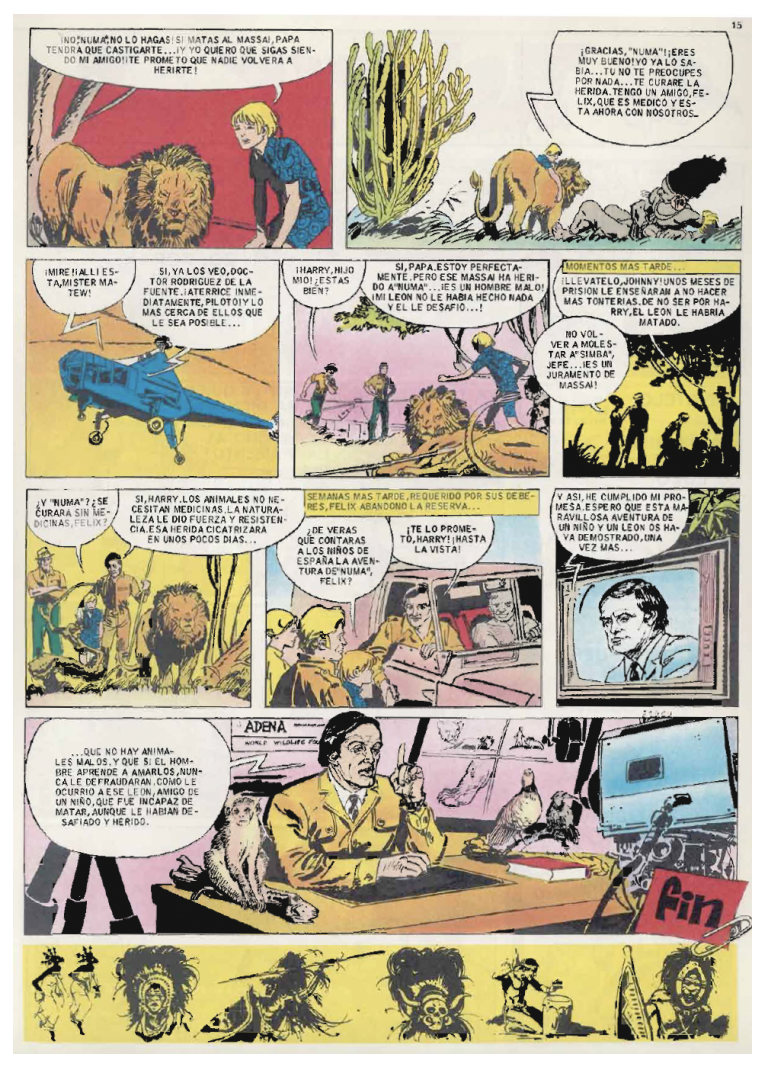

Figure 4. Gran Pulgarcito 72 [1970], p. 15.

led him to gladly lavish his knowledge upon others in accordance with a scholarship-driven virtuous ethos. Such a western, white male Wissenschaft was also a fundamental trait of the techno-scientific patriotism that was so needed in Spain according to the modernization promises of the regime [Daum, 2004].

Active participation and the making of young naturalists
With all these elements in place, the specific targeting of children and teenagers, both in terms of form and content, was an invitation to become familiar with the rightful and appropriate set of tools that would enable the necessary scientific inquiry. The aim was the technological taming, political-economic management, socio-cultural commodification and, ultimately, all-round consumption of the sublime, mysterious, dangerous, and bountiful wilderness, the useful backdrop for a civilised, developed, and modern society. This invitation was unambiguously rounded off in the third section of FRF's Gran Pulgarcito productions, a Q\&A section titled 'Félix dialoga con vosotros' ('Félix talks to you') (see Figure 3), which effectively encouraged the young to participate and give their best following FRF's lead.

FRF's understanding and pursuit of public exposure to raise awareness of taking care of the environment took into consideration the fact that the media, if used simply for propaganda and entertainment purposes, as the regime was keen on doing, could be just as alienating as the urban lack of exposure to nature he was fighting against. Nature was a hands-on endeavour, so FRF's aim was to go beyond media exposure, which could be simply conducive of couch awareness, and try to encourage direct participation. This could be considered a bold step under a 
regime that had been strenuously controlling people's everyday lives for decades, but also a reflection of the socio-cultural changes that were, at the time, bringing about an increasing demand for different modes of epistemological agency [Hamilton, 2017; Tabernero, 2018]. ${ }^{21}$

Q\&A sections typically feature a wide range of everyday experiences and subjectivities that simultaneously echo and contribute to the socio-cultural contexts of the medium in which they are published. They also entail the public exchange of ideas between experts and non-experts [Tabernero-Holgado, Jiménez-Lucena and Molero-Mesa, 2013]. Thus, Gran Pulgarcito's Q\&A section implied that FRF's comics were not just aimed at readers wishing to comfortably consume wilderness from their couches at home. The point was to engage them actively with nature by offering the opportunity to share their experiences in the form of letters that might eventually be deemed worthy of publication alongside FRF's own work.

The announcement on page 18 of issue 72, on 8 June 1970, featured another letter penned by FRF, in which he acknowledged the educational potential of comics as a shared, regular, and highly popular everyday communication practice. With a seamless combination of rhetorical coyness, his trademark closeness as 'friend Félix', which reinforced the fandom he was already generating among youngsters, and the reference to exotic, mysterious and exciting places, wildlife, and people, he eloquently stressed the importance of getting to know nature. ${ }^{22} \mathrm{He}$ also emphasised the need to share this knowledge and pointed out the importance of the projection of his young audiences into the future, suitably according to the ruling National-Catholic socio-cultural traits:

I am your friend Félix [...] And I must say that it really thrills me to be able to help you enter, by my side [...] the world of Nature [...] What would I not do for you, men (sic) of a brilliant future, to get to know and love the treasure that has been entrusted to us by the Creator?

[Gran Pulgarcito 72, 8 June 1970, p. 18]

The insistence on the shared-experience character of this mediated exploration of nature was even more persuasively appealing as those 'men of a brilliant future' were rhetorically placed at the level of the expert, just like FRF. Indeed, to clarify the nature of participation, another, less personal and more editorial text was included on the same page. Flanked by two photographs of FRF, one where he was holding a pair of binoculars and standing next to a film camera, and another where he was tending to one of his renowned falcons, this was the actual invitation to send letters to have a genuine conversation with FRF: 'to ask all you wish to know

\footnotetext{
${ }^{21}$ In the 1960s, the huge emigration wave, generated by the Development Plans, as well as the promotion of Spain as a holiday destination, vividly increased the movement of people, and thus of information, across Spain's borders, At the same time, people gradually modified their everyday media practices concerning the management of information and entertainment, upon the massive arrival of TV sets to households. Indeed, the regime's 1966 Press Act could very well be interpreted as an attempt to address all these changes without losing the tight political grip on the population. On Franco's regime as a whole, see Preston [1994]; specifically on censorship and its relationship with comics, Fernández Sarasola [2017] and Fernández Sarasola [2019]; and with natural history and environmental issues, Tabernero [2016], Tabernero [2018], Tabernero [2022], Hamilton [2017], Gil Farrero [2018] and Camprubí [2020].

${ }^{22}$ Regarding fandom and its connection with media-driven forms of socio-cultural participation, see Jenkins [2006] and Jenkins [2012].
} 
about the animals that you are especially interested in'. It also offered the readers the opportunity to 'take a picture with [an animal] and send it, explaining all its details, so that we can generously publish it in these pages'. This text, together with the pictures, effectively tried to blur the boundaries between the expert, FRF, and the non-experts, the young readers. These were asked to provide the same they could see in FRF's photographs, and then promised exposure. Those non-experts could thus soon, as they were already telling him by mail, join the ranks of expert naturalists or broadcasters [Tabernero, 2018]. ${ }^{23}$

The call started effectively working as planned six instalments later, from issue 78 on. The questions and answers were short and referred to morphological, habitat and behavioural aspects of different animals, mostly pets, and they, importantly, included the names of the contributors, significantly boys and girls. These pieces were crucially published alongside other reports and news, which enhanced the feeling that the young non-experts were becoming naturalists and broadcasters through a genuine shared experience.

FRF's wildlife comics constitute a remarkably illustrative case of the use of popular media in processes of construction of natural history knowledge. FRF and the cartoonists translated formal mechanisms of production and circulation of scientific knowledge into a highly trendy and accessible communication channel, both in terms of complexity and affordability. By doing so, they put in motion an unregulated means of environmental education for young people, their unambiguous main target, complementary to other popular media endeavours undertaken by FRF. In addition, they unequivocally tried to articulate an invitation for those young audiences to actively engage in the study and protection of the natural heritage. They did so by casting FRF as the knowledgeable mediator in documentary and fiction stories, and, in a particularly interactive way, with the Q\&A section that they ran in the most important publication where the comic stories were featured. In the end, these productions worked as supplementary pieces within FRF's complex transmedia endeavour that, at the same time, greatly helped to define.

FRF sought to change Spaniards' perception of their relationship with the environment in a context of increasing urban and industrial development and against a culture of often reckless exploitation of natural resources. In this sense, he thought it essential to simultaneously appeal to policy makers, scholars, and the public at large, both in rural and urban settings, thus recognizing the complexity of processes of knowledge construction and validation [Tabernero, 2016; Tabernero, 2018]. For this purpose, he could not simply resort to academic or official media but needed to use popular media and their wide audiences as the central elements of his coordinated, multiplatform effort. In fact, the interest on the part of Jesús Durán and the different publishing companies that took on the comics, reveals everyone's tacit acknowledgement of the existence of enough public interest in environmental issues and the natural sciences, and, thus, of the need for natural history popularizing efforts such as FRF's.

\footnotetext{
${ }^{23}$ FRF received thousands of letters written by his readers, listeners, and viewers throughout his media career. A staple of that correspondence were the letters written by children and youngsters, or by their parents, asking what was necessary to do or study in order to become someone like him. [Tabernero, 2016; Tabernero, 2018; Tabernero, 2022].
} 
Beyond aesthetic and plot development considerations, the result was ground-breaking in several senses. First, these comics were unique in their focus on wildlife and environmental concerns. Science comics across the political and cultural boundaries of the Cold War were mostly centred on the advances and promise of scientific, medical, and technological development, and only occasionally, as an application of these developments, on the management of natural resources.

Second, FRF's comics not only focused on wildlife and the environment as objects of concern, but also on the practices related to their study and its communication. They followed naturalistic standards as a token of seriousness, trust and credibility, while enthusiastically strove to mirror conventional televisual documentary approaches to put across nature conservation ideas. And the addition of collectible cards with explicit educational content pointed at the need to acquire a rigorous, scientific methodology to understand and enjoy nature.

Third, the casting of FRF himself as a fiction character in a sort of biopic of a living hero, whose adventures were the product of his work and efforts as a naturalist and a broadcaster, took the science popularization effort one important step further: it was an unambiguous attempt to overcome the traditional separation between the serious, expert endeavours of producing and managing scientific-technical knowledge, and the playful, adventurous, and more emotionally recognizable application of that knowledge in everyday life, albeit fictional and heroic, situations. FRF, as hero, served as an example, for the targeted young audiences of these comics, of what could be achieved, in terms of scientific proficiency and public celebrity, by the study of the natural sciences and, additionally, by the professional pursuit of media practices.

And fourth, but no less importantly, all these elements were crowned by a persistent call for participation through a Q\&A section about animals, plainly aimed at actively engaging young readers in naturalist and media practices in whatever their everyday-life involvements with animals. This call openly thinned the boundaries between the expert and the non-experts by inviting children and teenagers to mirror FRF's activities. With a promise of public visibility in the same magazines, readers were enticed into telling and documenting their experiences, in effect, like naturalists and broadcasters who could eventually become scientific heroes and celebrities, as these comics were depicting within FRF's insistently cross-referential transmedia effort.

The success of this approach needs to be considered within the framework of the use of media outlets in the dictatorship as routes of indoctrination and disciplining through submission and obedience to experts. These comics complied with the regime's media communication standards and restrictions, while they played with the regime's idiosyncratic propaganda concerns and strategies related to its status in the international arena and crucial promises of modernization. The depiction of nature was based upon a consideration of wilderness as an exotic, distant, sublime, dangerous and mysterious realm, which was to be understood and managed in explicitly colonial albeit scientifically responsible terms. Human and non-human resources were to be civilised across established race, class, and gender boundaries, thus maintaining traditional epistemological ranks. Based on this premise, the Spanish naturalist, FRF, exerted a scientific-technological patriotism, articulated as 
green colonialism, that could only be informed by a corresponding rigorous and compassionate Wissenschaft. By extension, the young readers, conceivable professionals of the future, would do so under equal conditions to those of western, white male managers. And to underline the scientific-green character of such a colonial endeavour while in accordance with the rising environmental concerns of the time, the 'bad guys' were also white males driven by urban-industrial ignorance and selfishness who exploited the colonised indigenous peoples' easily malleable need and superstition.

This paper thus offers a historical reading of a range of media practices around the creation and consumption of comics where nature and the environment were deemed essential objects of scientific concern. FRF's active self-construction as a celebrity naturalist, together with the transmedia structure of his science popularization ventures, were extremely powerful tools in enticing his audiences to consider certain forms of participation and epistemological agency. It was clear to him that nature was a pro-active endeavour, and, by these means, he aimed to create a young fandom of potential naturalists who, by way of example, were to be equipped with the patriotic, green colonial ethics of a devoted worker, very much to the regime's liking, while scientifically driven and informed.

Acknowledgments

I am indebted to Fundación Félix Rodríguez de la Fuente, and particularly Odile Rodríguez de la Fuente, for their invaluable support and assistance with the FRF's archive. I am also very grateful to Agustí Nieto, Clara Florensa and Oliver Hochadel for their comments and suggestions, and to Ronnie Lendrum for her thorough copy-editing. This research was funded by the PID2019-106208GBI00 (Urban Narratives About Nature. Contemporary Construction of Natural History Knowledge) grant of the Ministerio de Ciencia e Innovación (Spanish Department of Science and Innovation). It was also in part supported by the Grup de Recerca Consolidat i Finançat 2017SGR1138 (Generalitat de Catalunya) grant.

\section{Disclaimer}

Reproduction of comic illustrations: as far as possible, the required permissions were requested or obtained from the original publishers and/or copyright holders. In some instances this was not possible, i.e. where comics were published more than 50 years ago or the original publisher no longer exists.

\section{References}

Agar, J. and Ward, J., eds. (2018). Histories of technology, the environment and modern Britain. London, U.K.: UCL Press. https://doi.org/10.2307/j.ctvqhsmr.

Altarriba, A., ed. (2011). La historieta española, 1857-2010. Historia, sociología y estética de la narrativa gráfica en España. Arbor 187 (Núm. Extra_2), pp.9-287. https://doi.org/10.3989/arbor.2011.iExtra_2.

Andrews, J. T. (2013). 'An evolving scientific public sphere: state science enlightenment, communicative discourse, and public culture from imperial Russia to Khrushchev's Soviet times'. Science in Context 26 (3), pp. 509-526. https://doi.org/10.1017/s0269889713000161.

Armiero, M. (2008). 'Seeing like a protester: nature, power, and environmental struggles'. Left History 13 (1), pp. 59-76. https://doi.org/10.25071/1913-9632.24610. 
Armiero, M. and Graf von Hardenberg, W. (2013). 'Green rhetoric in blackshirts: Italian Fascism and the environment'. Environment and History 19 (3), pp. 283-311. https://doi .org/10.3197/096734013x13690716950064.

Augustine, D. L. (2007). Red Prometheus: engineering and dictatorship in East Germany, 1945-1990. Cambridge, MA, U.S.A.: The MIT Press. https://doi.org/10.7551/mitpress/7446.001.0001.

Bell, E. and Gray, A. (2007). 'History on television: charisma, narrative and knowledge'. European Journal of Cultural Studies 10 (1), pp. 113-133. https://doi.org/10.1177/1367549407072973.

Bocking, S. (2004). Nature's experts: science, politics, and the environment. New Brunswick, NJ, U.S.A.: Rutgers University Press.

Breiby, M. A. (2014). 'Exploring aesthetic dimensions in a nature-based tourism context'. Journal of Vacation Marketing 20 (2), pp. 163-173. https://doi.org/10.1177/1356766713514243.

Brockington, D. (2008). 'Powerful environmentalisms: conservation, celebrity and capitalism'. Media, Culture \& Society 30 (4), pp. 551-568. https://doi.org/10.1177/01634437080300040701.

Burns, M. and Leach, J. (2011). 'Science as an extra dividend: Frontiers of Science'. International Journal of Cultural Studies 14 (5), pp. 531-546. https://doi.org/10.1177/1367877910382190.

Callon, M. (1999). 'The role of lay people in the production and dissemination of scientific knowledge'. Science, Technology and Society 4 (1), pp. 81-94. https://doi.org/10.1177/097172189900400106.

Camprubí, L. (2020). 'Birds without borders: ecological diplomacy and the WWF in Franco's Spain'. Historical Studies in the Natural Sciences 50 (4), pp. 433-455. https://doi.org/10.1525/hsns.2020.50.4.433.

Chris, C. (2006). Watching wildlife. Minneapolis, MN, U.S.A.: University of Minnesota Press.

Cronon, W. (1996). 'The trouble with wilderness: or, getting back to the wrong nature'. Environmental History 1 (1), pp. 7-28. https://doi.org/10.2307/3985059.

Cuadrado, J. (2000). Atlas español de la cultura popular: de la historieta y su uso 1873-2000. Madrid, Spain: Ediciones Sinsentido.

Daum, A. W. (2004). 'Wissenschaft and knowledge'. In: Germany 1800-1870. Ed. by J. Sperber. Oxford, U.K.: Oxford University Press, pp. 137-161.

- (2009). 'Varieties of popular science and the transformations of public knowledge: some historical reflections'. Isis 100 (2), pp. 319-332. https://doi.org/10.1086/599550.

Farinella, M. (2018). 'The potential of comics in science communication'. JCOM 17 (01), Y01. https://doi .org/10.22323/2.17010401.

Fernández Sarasola, I. (2017). La legislación sobre historieta en España. Barcelona, Spain: ACyT Ediciones.

- (2019). El pueblo contra los comics. Barcelona, Spain: ACyT Ediciones.

García, S. (2010). La novela gráfica. Bilbao, Spain: Astiberri Ediciones.

Gil Farrero, J. (2018). 'Natura en conflicte. La construcció del patrimoni natural a Catalunya, del franquisme a la democràcia (1955-1992)'. Ph.D. thesis. Bellaterra, Spain: Centre d'Història de la Ciència, Universitat Autònoma de Barcelona. URL: http://hdl . handle.net/10803/664107.

Gissibl, B., Höhler, S. and Kupper, P., eds. (2012). Civilizing nature: national parks in global historical perspective. New York, NY, U.S.A.: Berghahn Books. 
Goulart, R. (2000). Comic book culture: an illustrated history. Portland, OR, U.S.A.: Collectors Press.

- (2004). Comic book encyclopedia: the ultimate guide to characters, graphic novels, writers, and artists in the comic book universe. New York, NY, U.S.A.: HarperCollins.

Gouyon, J.-B. (2011). 'From Kearton to Attenborough: fashioning the telenaturalist's identity'. History of Science 49 (1), pp. 25-60. https://doi.org/10.1177/007327531104900102.

- (2019). BBC wildlife documentaries in the age of Attenborough. London, U.K.: Palgrave MacMillan. https://doi .org/10.1007/978-3-030-19982-1.

Guiral, A. (2010). 100 años de Bruguera: de El Gato Negro a Ediciones B. Barcelona, Spain: Ediciones B.

Hajdu, D. (2008). The ten-cent plague: the great comic-book scare and how it changed America. New York, NY, U.S.A.: Farrar, Straus and Giroux.

Hamilton, S. R. (2017). 'Environmental change and protest in Franco's Spain, 1939-1975'. Environmental History 22 (2), pp. 257-281. https://doi.org/10.1093/envhis/emw119.

Hilgartner, S. (1990). 'The dominant view of popularization: conceptual problems, political uses'. Social Studies of Science 20 (3), pp. 519-539. https://doi.org/10.1177/030631290020003006.

- (2000). Science on stage: expert advice as public drama. Stanford, CA, U.S.A.: Stanford University Press. https://doi .org/10.1515/9781503618220.

Irwin, A. and Wynne, B., eds. (1996). Misunderstanding science? The public reconstruction of science and technology. Cambridge, U.K.: Cambridge University Press. https://doi .org/10.1017/cbo9780511563737.

Jasanoff, S., ed. (2004). States of knowledge: the co-production of science and the social order. London, U.K.: Routledge. https://doi.org/10.4324/9780203413845.

Jenkins, H. (2006). Fans, bloggers, and gamers: exploring participatory culture. New York, NY, U.S.A.: NYU Press.

- (2010). 'Transmedia storytelling and entertainment: an annotated syllabus'. Continuum 24 (6), pp. 943-958. https://doi.org/10.1080/10304312.2010.510599.

- (2012). 'Quentin Tarantino's Star Wars? Digital cinema, media convergence, and participatory culture'. In: Media and cultural studies: keyworks. Ed. by M. G. Durham and D. M. Kellner. Malden, MA, U.S.A.: Wiley-Blackwell, pp. $452-471$.

Jiménez Varea, J. (2011). ‘Formas y contenidos. Evolución del lenguaje y de los argumentos en la historieta española'. Arbor 187 (Núm. Extra_2), pp. 43-61. https://doi.org/10.3989/arbor.2011.2extran2113.

Jones, W. B. (2011). Classics illustrated: a cultural history. Jefferson, NC, U.S.A.: McFarland \& Company.

Kirby, D. A. (2008). 'Hollywood knowledge: communication between scientific and entertainment cultures'. In: Communicating science in social contexts: new models, new practices. Ed. by D. Cheng, M. Claessens, T. Gascoigne, J. Metcalfe, B. Schiele and S. Shi. Dordrecht, The Netherlands: Springer, pp. 165-180. https://doi.org/10.1007/978-1-4020-8598-7_10.

Kusiak, P. (2010). 'Instrumentalized rationality, cross-cultural mediators, and civil epistemologies of late colonialism'. Social Studies of Science 40 (6), pp. 871-902. https://doi.org/10.1177/0306312710372436. 
Labanyi, J., ed. (2002). Constructing identity in contemporary Spain: theoretical debates and cultural practice. Oxford, U.K.: Oxford University Press.

Leach, J. (2015). 'A comic moment for social epistemology'. In: The future of social epistemology: a collective vision. Ed. by J. H. Collier. London, U.K.: Rowman \& Littlefield.

Louson, E. (2018). 'Taking spectacle seriously: wildlife film and the legacy of natural history display'. Science in Context 31 (1), pp. 15-38. https://doi.org/10.1017/s0269889718000030.

Medina-Doménech, R. (2009). 'Scientific technologies of national identity as colonial legacies: extracting the Spanish nation from Equatorial Guinea'. Social Studies of Science 39 (1), pp. 81-112. https://doi.org/10.1177/0306312708097658.

Moix, T. (2007). Historia social del cómic. Barcelona, Spain: Bruguera.

Nelson, M. P. and Callicott, J. B., eds. (2008). The wilderness debate rages on. Athens, GA, U.S.A.: University of Georgia Press.

Neumann, R. P. (2002). Imposing wilderness: struggles over livelihood and nature preservation in Africa. Berkeley, CA, U.S.A.: University of California Press.

Olmstead, K. (2008). Jacques Cousteau: a life under the sea. New York, NY, U.S.A.: Sterling.

Pintor Iranzo, I. (2017). Figuras del cómic: forma, tiempo y narración secuencial. Barcelona, Spain: Universitat Pompeu Fabra, Universitat Autònoma de Barcelona.

Plumwood, V. (1993). Feminism and the mastery of nature. London, U.K.: Routledge. https://doi.org/10.4324/9780203006757.

Preston, P. (1994). Franco: a biography. New York, NY, U.S.A.: HarperCollins.

Salcedo, M. (2008). ‘El documental de divulgación científica sobre la naturaleza: técnicas narrativo-dramáticas y retóricas empleadas por Félix Rodríguez de la Fuente en El Hombre y la Tierra'. Ph.D. thesis. Pamplona, Spain: Universidad de Navarra.

Sánchez Sánchez, E. M. (2001). ‘El auge del turismo europeo en la España de los años sesenta'. Arbor 170 (669), pp. 201-224. https://doi.org/10.3989/arbor.2001.i669.918.

Scott, K. D. (2003). 'Popularizing science and nature programming: the role of "Spectacle" in contemporary wildlife documentary'. Journal of Popular Film and Television 31 (1), pp. 29-35. https://doi .org/10.1080/01956050309602866.

Somsen, G. (2017). 'Science, Fascism, and foreign policy: the exhibition "Scienza Universale" at the 1942 Rome World's Fair'. Isis 108 (4), pp. 769-791. https://doi.org/10.1086/695758.

Tabernero, C. (2016). '«La libertad de todos los seres vivos». Naturaleza, ciencias naturales y la imagen de España en la obra de Félix Rodríguez de la Fuente'. Arbor 192 (781), a345. https://doi.org/10.3989/arbor . 2016.781n5003.

- (2018). 'The changing nature of modernization discourses in documentary films'. Science in Context 31 (1), pp. 61-83. https://doi.org/10.1017/s0269889718000066.

- (2022). 'The case of the killer she-wolf. Media, science, and the construction of the environment in late Franco's Spain (1965-1978)'. Historical Studies in the Natural Sciences. In press.

Tabernero, C., Jiménez-Lucena, I. and Molero-Mesa, J. (2017). ‘Colonial scientific-medical documentary films and the legitimization of an ideal state in post-war Spain'. História, Ciências, Saúde-Manguinhos 24 (2), pp. 349-369. https://doi.org/10.1590/s0104-59702016005000025. 
Tabernero-Holgado, C., Jiménez-Lucena, I. and Molero-Mesa, J. (2013).

'Movimiento libertario y autogestión del conocimiento en la España del primer tercio del siglo XX: la sección "Preguntas y respuestas" (1930-1937) de la revista Estudios'. Dynamis 33 (1), pp. 43-67.

https://doi.org/10.4321/s0211-95362013000100003.

Turner, G. (2004). Understanding celebrity. London, U.K.: SAGE Publications.

Vázquez, J. M. (1973). 'Estudio sociográfico de la actual prensa infantil y juvenil en España'. Revista Española de la Opinión Pública (32), pp. 65-90. https://doi.org/10.2307/40181908.

Wakild, E. (2011). Revolutionary parks: conservation, social justice, and Mexico's national parks, 1910-1940. Tucson, AZ, U.S.A.: The University of Arizona Press.

Wertham, F. (1954). Seduction of the innocent. New York, NY, U.S.A.: Rinehart.

Wheatley, H. (2013). 'At home on safari: colonial spectacle, domestic space and 1950s television'. Journal of British Cinema and Television 10 (2), pp. 257-275. https://doi.org/10.3366/jbctv.2013.0134.

Author

Carlos Tabernero is an associate professor of History of Science at the Institute of History of Science of the Autonomous University of Barcelona (Spain). His research, publications and teaching focus on media and the production, communication, and management of scientific knowledge. His current research project, funded by the Spanish Department of Science and Innovation, focuses on processes of construction and circulation of natural history knowledge, specifically concerning urban narratives about nature in the 20th century.

E-mail: carlos.tabernero@uab.cat.

\section{How to cite}

Tabernero, C. (2022). 'Wildlife comics, or the making of young naturalists in late Franco's Spain (1969-1970)'. JCOM 21 (01), A05.

https://doi.org/10.22323/2.21010205. 